\title{
Effects of Changed Climate Conditions on Tropospheric Ozone over Three Centuries
}

\author{
Gitte Brandt Hedegaard ${ }^{1,2,3}$, Jesper Heile Christensen ${ }^{1}$, Camilla Geels ${ }^{1}$, Allan Gross ${ }^{1}$, \\ Kaj Mantzius Hansen ${ }^{1}$, Wilhelm May ${ }^{2}$, Azimeh Zare ${ }^{1,4}$, Jørgen Brandt ${ }^{1}$ \\ ${ }^{1}$ Department of Environmental Science, Aarhus University, Roskilde, Denmark \\ ${ }^{2}$ Danish Climate Centre, Danish Meteorological Institute, Copenhagen, Denmark \\ ${ }^{3}$ Centre for Environmental and Climate Research, Lund University, Lund, Sweden \\ ${ }^{4}$ Institute of Geophysics, University of Tehran, Tehran, Iran \\ Email: jbr@dmu.dk, gitte.brandt_hedegaard@cec.lu.se
}

Received June 8, 2012; revised July 10, 2012; accepted July 21, 2012

\begin{abstract}
The ozone chemistry in four decades (1890s, 1990s, 2090s and 2190s) representing the changes over three centuries has been simulated using the chemistry version of the atmospheric long-range transport model: the Danish Eulerian Hemispheric Model (DEHM) forced with meteorology projected by the ECHAM5/MPI-OM coupled Atmosphere-Ocean General Circulation Model. The largest changes in meteorology, ozone and its precursors are found in the 21st century, however, also significant changes are found in the 22nd century. At surface level the ozone concentration is projected to increase due to climate change in the areas where substantial amounts of ozone precursors are emitted. Elsewhere a significant decrease is projected at the surface. In the free troposphere a general increase is found in the entire Northern Hemisphere except in the tropics, where the ozone concentration is decreasing. In the Arctic the ozone concentration will increase in the entire air column, which most likely is due to changes in atmospheric transport. Changes in temperature, humidity and the naturally emitted Volatile Organic Compounds (VOCs) are governing the changes in ozone both in the past, present and future century.
\end{abstract}

Keywords: Ozone; Climate Change; Air Quality; Modelling

\section{Introduction}

Since the industrialization the concentration of greenhouse gases in the atmosphere has increased. The greenhouse gases affect our climate, which has been undergoing a continuous change into what we experience today. Atmospheric chemistry is highly dependent on temperature, humidity and solar radiation and the observed warming will inherently affect the chemical composition of the atmosphere.

The effect of changes in meteorology on air pollution levels implies that even though we today decide to keep the anthropogenic emissions of air pollutants constant, the air pollution levels will change anyway in response to climate change.

This paper focus on ozone, which in the lower troposphere acts as a toxic gas that through respiratory and cardiovascular diseases can lead to premature death of humans. Furthermore ozone is harmful to plants in high concentrations and can diminish the crop yield substantially. Since air pollutants like ozone can have tremendous effect on human health, agriculture, the terrestrial and marine eco-systems etc., it is important to project the future air pollution levels. These findings can be used to develop and implement new air pollution legislation, which hopefully will minimize the negative consequences of human interference with the environment.

So far the research community has concentrated on air quality in the 21 st century [1-6]. Here we use a 340 -year long climate simulation to investigate ozone and its related precursors in the past, present and future. We focus on the impacts of climate change alone by keeping the anthropogenic emissions constant at a year 2000 level. In Section 2 the climate model and the applied climate simulation are described. Section 3 describes the applied chemistry model and the experimental setup and finally the results are displayed and discussed in relation to the chemical reactions included in the model in Sections 4 and 5. In Section 6 the findings are summarized together with some future perspectives.

\section{Climate Projections Using ECHAM5/MPI-OM}

The coupled atmosphere-ocean model ECHAM5/ MPIOM used to drive the chemical transport model DEHM 
consists of the atmospheric general circulation model ECHAM5 [7,8] and the ocean-sea-ice model MPI-OM [9]. The atmospheric model ECHAM5 is horizontally defined in a spectral grid with truncation T63. Vertically the model is defined in a hybrid sigma-pressure system and divided into 31 layers with the top layer at $10 \mathrm{hPa}$. State-of-the-art parameterizations are used for shortwave and long-wave radiation, stratiform clouds, boundary layer and land-surface processes and for describing gravity wave drag in the model. A description of the aerosol effect included in this model version can be found in [10].

The ocean-sea-ice model has a horizontal resolution of $1.5^{\circ} \times 1.5^{\circ}$ and is vertically discretized into $40 \mathrm{z}$-levels. Concentration and thickness of sea ice is treated interactively in the model by a dynamic and thermodynamic sea-ice model. For further details of the ocean-sea-ice model, see [9].

The atmosphere model ECHAM5 and the ocean-seaice model MPI-OM is interactively coupled and exchange information regarding sea-surface temperature, sea-ice concentration and thickness, wind stress, heat and freshwater once a day. Further details of the coupling can be found in [10] and [11]. The model does not employ flux adjustments. The coupling of the atmosphere and ocean model has been tested by [11] and is found to perform well with respect to sea surface temperatures, seaice conditions, meridional heat transport and transport of freshwater [10].

The specific climate simulation used in this experiment is forced with emissions, based on realistic estimations until year 2000 and emissions according to the SRES A1B scenario in the period 2000-2100. In the final period 2101-2200 all the emissions have been fixed at a 2100-level. The SRES A1B scenario assumes a future world with very rapid economic growth and a rapid introduction of new and more efficient technologies balanced between both fossil - and non-fossil intensive energy sources. The population growth peaks in about 2050 and declines hereafter [12]. It should be noted that this forcing from emissions only applies to the projected meteorology. The anthropogenic emissions used in the DEHM model are kept constant in order to isolate the signal from climate change on the air pollution levels.

\section{Projected Meteorology}

The climate simulation applied in this study was part of the 4th IPCC Assessment Report (AR4) multi-model ensemble study. In the current simulation the global temperature is projected to increase by $3.0^{\circ} \mathrm{C}$ by the end of the 21 st century and by $4.3{ }^{\circ} \mathrm{C}$ by the end of the $22 \mathrm{nd}$ century, both relative to the period 1971-2000 [10]. This increase is a little higher than the average value $\left(2.7^{\circ} \mathrm{C}\right.$ and $3.4^{\circ} \mathrm{C}$, respectively) projected by the multi-model ensemble following the SRES A1B scenario in the AR4 [13]. However, it is well within the standard deviation of the IPCC AR4 multi-model ensemble by the end of the 21 st century. In Figure 1 the mean temperature at the lowest model level of the four decades (1890s, 1990s, 2090s and 2190s) considered in this study is plotted (upper panel) together with the absolute change between these decadal mean values (center panel) and the signifycance of these changes (lower panel) using a student's t-test [14]. Temporally the temperature is increasing significantly in the two future decades (2090s and 2190s) relative to the 1990s. The ECHAM5/MPI-OM model simulation generally also projects a temperature increase in the 20th century (represented by the difference between the 1990s and the 1890s), however, this increase is only significant in the tropics. Further, a temperature decrease is projected over the North Atlantic storm tracks in the former period (1990s minus 1890s).

The absolute largest temperature increase is found in the 21 st century (see centre plot of Figure 1). This is in line with results from [10] who found that the changes in the global annual mean near-surface temperature is largest around year 2060 with a warming rate of more than. $4.5^{\circ} \mathrm{C}$. This high warming rate is due to a strong increase in all greenhouse gases except methane and a marked reduction in the anthropogenic sulphur emissions according to the SRES A1B emission scenario. Focus- sing on the 21 st century (2090s-1990s) the temperature increase is largest in the Arctic region, where it locally exceeds $9^{\circ} \mathrm{C}$. Over land areas in general the temperature increase ranges from $3^{\circ} \mathrm{C}$ to $6^{\circ} \mathrm{C}$ and over the ocean the increase is more modest in the range $1^{\circ} \mathrm{C}$ to $4^{\circ} \mathrm{C}$.

The projected temperature change found in the $21 \mathrm{st}$ century is continuing into the 21 st century with reduced strength.

In Figure 2 results for the specific humidity is shown. The specific humidity is closely related to the atmospheric temperature. At saturation the specific humidity is a quasi-exponential function of temperature according to the Clausius-Clapeyron equation [15]. This exponential dependency implies that the change in humidity is significantly largest at low latitudes (where the highest temperature is projected). The specific humidity distribution follows the latitudes very closely (Figure 2). As the projected temperature field (Figure 1), the specific humidity also shows the absolute largest changes within the 21 st century (middle panel of Figure 2). In the 21 st century the projected change in specific humidity is only significant in the tropical region. Vertically the largest change in specific humidity is confined to the lowest part of the troposphere where most water vapour in the atmosphere is found, in contrast to the vertical profile of temperature change, which is rather uniform.

The shortwave radiation depends on both space and time and is derived from the cloud cover calculated by 


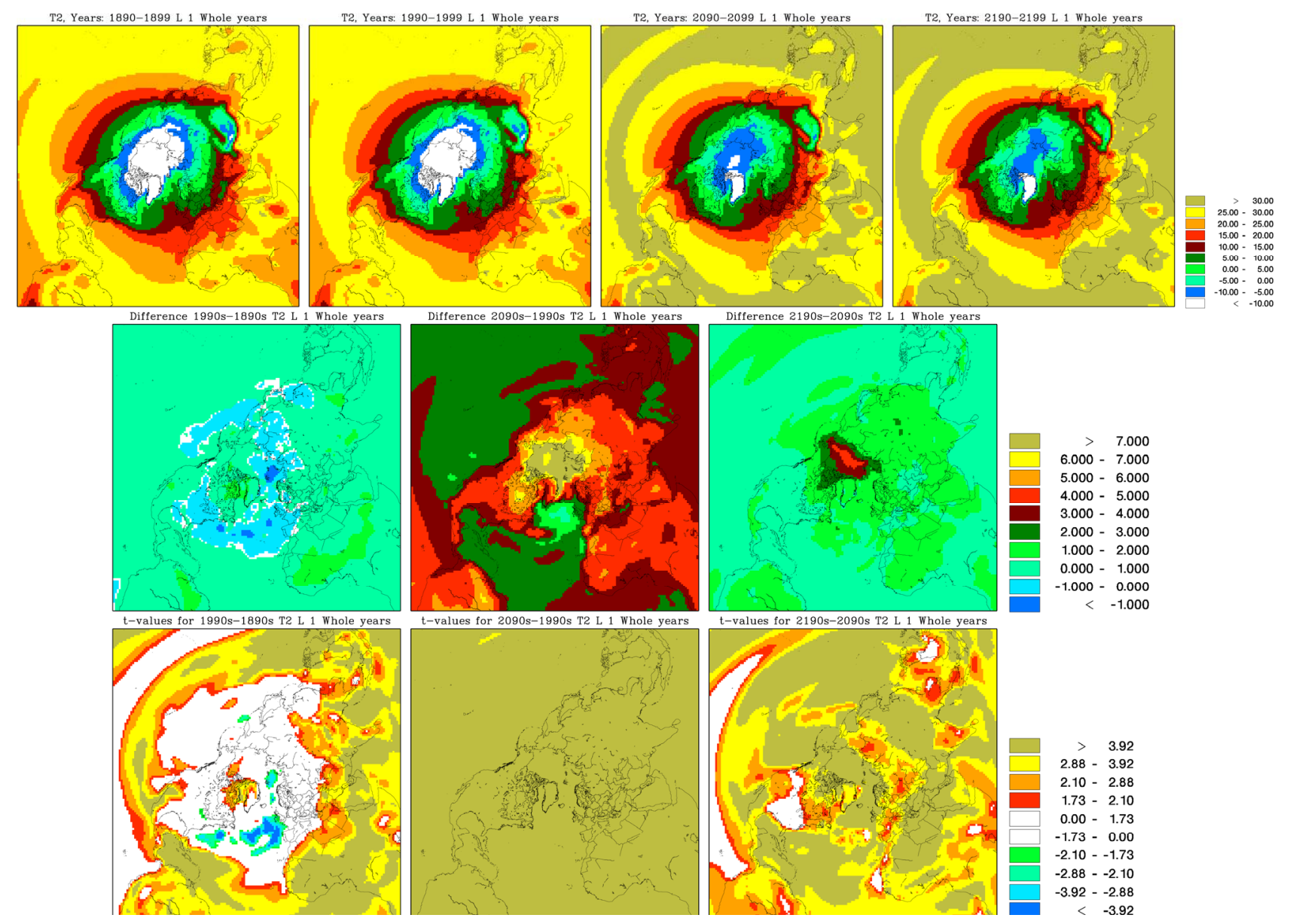

Figure 1. Top panel: Decadal mean temperature of the lowest model layer in ${ }^{\circ} \mathrm{C}$ of the decades; $1890 \mathrm{~s}, 1990 \mathrm{~s}, 2090 \mathrm{~s}$ and $2190 \mathrm{~s}$. Middle panel: The difference in ${ }^{\circ} \mathrm{C}$. Bottom panel: The significance of the differences according to the students t-test [14]. The threshold value for significance is chosen to $10 \%$ (white areas indicates no significant change).

ECHAM5 according to the method used in [16]. In Figure 3 the shortwave radiation of the four decades is shown together with the difference and the significance of these differences. The largest changes are projected in 21 st century, where the shortwave radiation is projected to increase in the southern mid-latitudes and the subtropics. This is in line with the general idea that the Earth in the future will experience longer and more persistent periods with drought and high temperatures in the subtropics [17]. In contrast to the temperature and specific humidity, the change in shortwave radiation is only significant in the 21 st century (see lower panel, Figure 3). The projected change is highly dependent on latitude and is increasing everywhere in the domain, except over the tropical Pacific Ocean.

Since the shortwave radiation is derived from latitude and the cloud cover from ECHAM5, the area of decreasing shortwave radiation over the tropical Pacific most likely is due to an increase in cloud cover in the climate simulation. The ECHAM5/MPI-OM simulation has been part of the multi-model ensembles of 4th IPCC report
(AR4), which confirms a general increase in cloud cover over the tropical Pacific [13]. In central and southern Europe the shortwave radiation is projected to increase more than $20 \%$, which is in good agreement with the theory of longer and more persistent periods of dry warm summers in the future at these latitudes $[18,19]$.

\section{The Danish Eulerian Hemispheric Model}

The Atmospheric Chemistry Transport Model, DEHM (Danish Eulerian Hemispheric Model) [20-22] has been driven on meteorology of the past, present and future projected by the ECHAM5/MPI-OM Atmosphere-Ocean General Circulation Model [7,8,10] forced with the IPCC SRES A1B emission scenario [12]. Ozone and the related photochemical species have been investigated thoroughly in four decades (1890s, 1990s, 2090s and 2190s) with respect to the impacts of climate change. A thorough statistic analysis using construction of Empirical Orthogonal Function (EOF) and surrogate data has shown that the four chosen decades (1890s, 1990s, 2090s and 2190s) is 


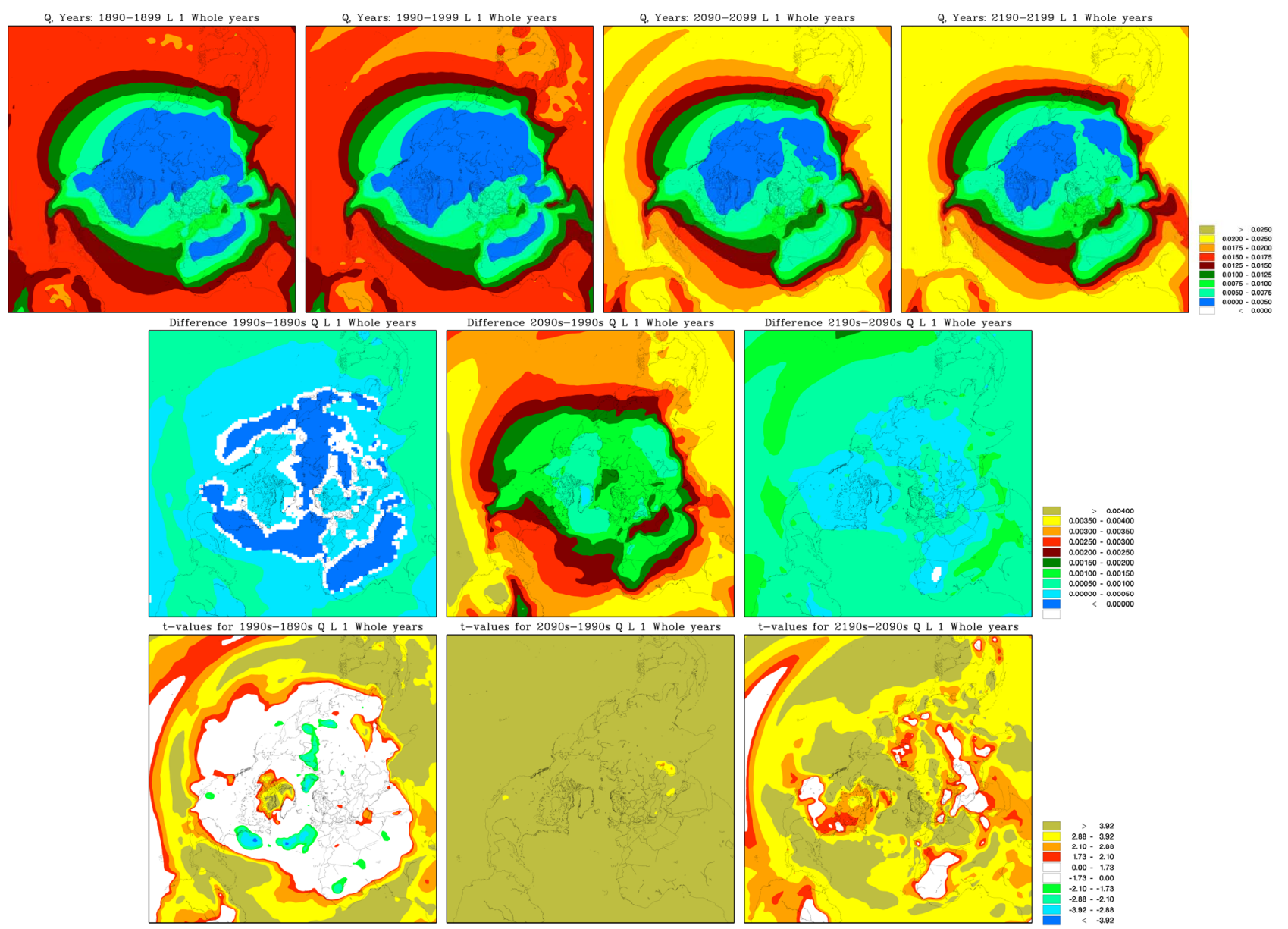

Figure 2. Average decadal specific humidity in the lowest model layer in $\mathrm{Kg} \cdot \mathrm{Kg}^{-1}$. Setup the same as Figure 1.

representing the internal variability of the full 340-year long period within a significance level of $10 \%$ [23]. The performance of the full model system with ECHAM5/ MPI-OM model coupled to the DEHM model system has been thoroughly tested in earlier studies $[3,16]$.

In the current model setup, the model domain covers slightly more than the Northern Hemisphere (see Figure 1). The horizontal grid has a resolution of $150 \mathrm{~km} \times 150$ $\mathrm{km}$ using a polar stereographic projection true at $60^{\circ} \mathrm{N}$. Vertically the model consists of 20 unevenly distributed layers defined on terrain following $\sigma$-levels extending up to a height of approximately $16 \mathrm{~km}(100 \mathrm{hPa})$. Boundary conditions for the model domain depend on the direction of the wind, such that free boundary conditions are used for sections where wind flows out of the domain. Constant boundary conditions are used for sections of the boundary where wind is flowing into the domain; in this case, the boundary value is set to the annual average background concentration. For ozone these are taken from ozone soundings [24] and are the same for all simulations in this study.

The chemistry scheme in DEHM is based on the European Monitoring and Evaluation Programme (EMEP) scheme [25]. The model describes concentration fields of 58 chemical species, including secondary inorganic particles and 7 species representing primarily emitted particulate matter $\left(\mathrm{PM}_{2.5}, \mathrm{PM}_{10}\right.$, TSP, sea-salt, fresh black carbon, aged black carbon and organic carbon). A total of 122 chemical reactions are included. Wet and dry deposition is parameterized similar to the EMEP model [25], except for the dry deposition of species on water surfaces. In this case, the deposition depends on the solubility of the chemical specie and the wind speed (for further details see $[26,27]$ ). Details about the numerics can be found in $[20,28-30]$.

\section{Emissions}

The anthropogenic emissions that have been used as input to the chemistry transport model DEHM have been fixed at a year 2000 level to isolate the signal from climate change on air pollution. The emissions of the pri mary pollutants consist of data from the Global Emissions Inventory Activity (GEIA) [31], the Emission Database for Global Atmospheric Research (EDGAR) [32] both with global coverage, and the EMEP emissions [33] covering Europe. The GEIA database includes natural 


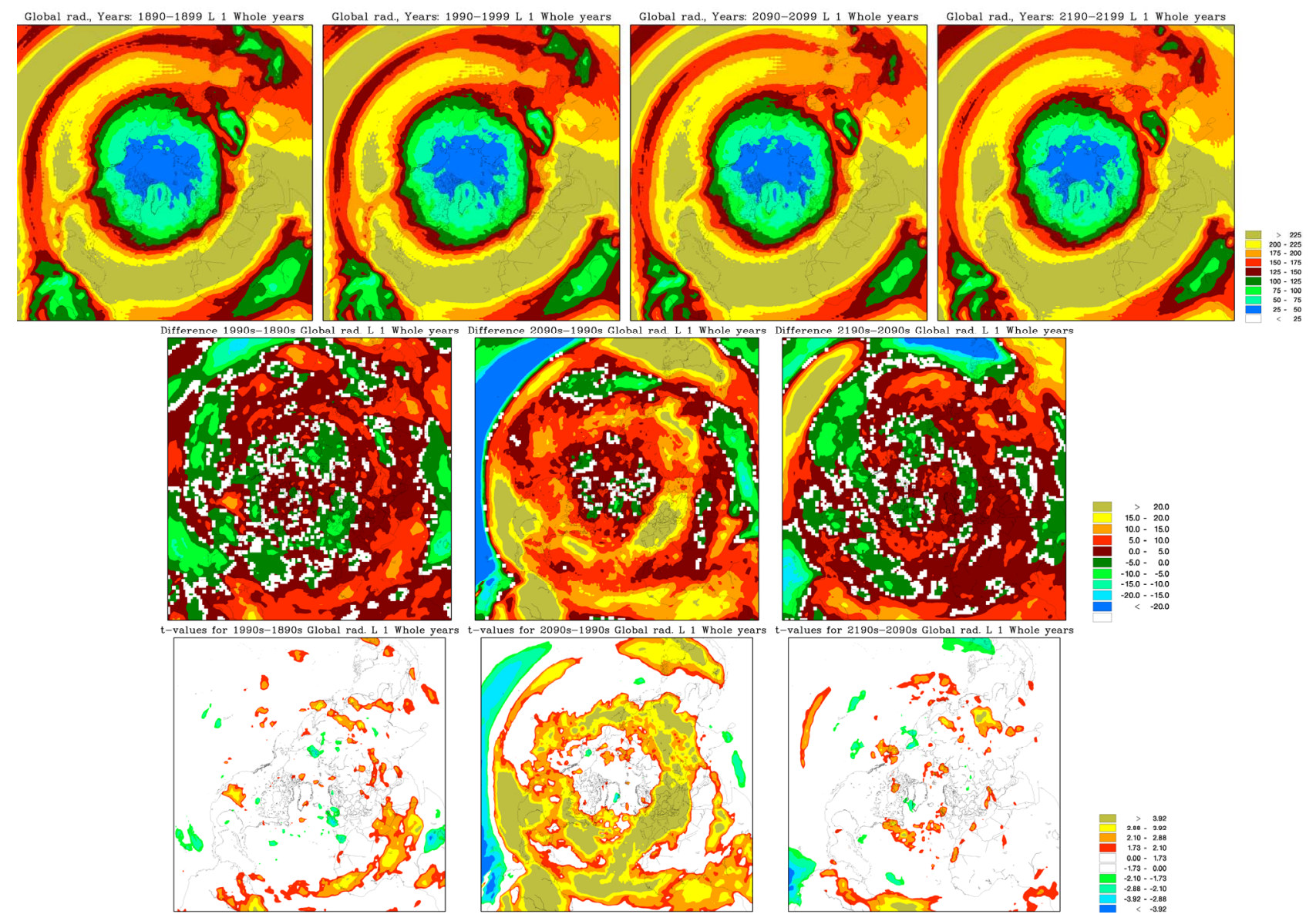

Figure 3. Average decadal shortwave radiation in the lowest model layer in $\mathrm{Wm}^{-2}$. Setup same as Figure 1.

emissions of $\mathrm{NO}_{\mathrm{x}}$ from soil and lightning and Black Carbon, which mainly originates from biomass burning. These natural emissions have also been fixed at a year 2000 level.

On the contrary the emission of isoprene is calculated dynamically in the model according to the GEIA natural VOC emission model [34]. GEIA is an empirically based emission scheme which simulates changes in temperature and sunlight (as two main environmental controls) on isoprene emission factors, which are ecosystem dependent isoprene emission rates at standard conditions $\left(30^{\circ} \mathrm{C}\right.$ and $1000 \mu \mathrm{mol} \cdot \mathrm{m}^{-2} \cdot \mathrm{s}^{-1}$ photon flux). The GEIA natural VOC emission model uses 59 different ecosystem types and assigns each area of the Earth's land surface to one of these terrestrial ecosystems. In [34] isoprene emission factors for each ecosystem can be found and the natural VOC emission model GEIA calculates the total flux of isoprene as the sum of emissions from each ecosystem within every grid cell.

\section{Results}

In Figure 4 the distribution (upper panel), the differences (centre panel) and the significance (lower panel) of the ten-year average $\mathrm{O}_{3}$ concentrations in ppbV is displayed. In all four decades surface $\mathrm{O}_{3}$ concentration is highest in the subtropics and the tropics over land, especially close to the anthropogenic precursor sources and downstream from these. A local measured ozone concentration consists of a local, a regional, and an inter-continental (background) contribution, which depends on the distance to the precursor sources, the local photochemical cond- itions and the transport pathways. The concentration distribution plotted in Figure 4 (upper panel) reflects these features well.

The centre panel of Figure 4 shows the projected differences in ozone concentration. The most pronounced change is found in the 21 st century with a general decrease over the ocean and very remote areas (as e.g. the desert of Sahara and central Asia) and an increase over the densely populated areas and areas dominated by dense vegetation and thereby high biogenic isoprene emissions. The change in concentrations over the Arctic Ocean differs from the above pattern. The Arctic is a remote and clean area with respect to $\mathrm{NO}_{\mathrm{x}} / \mathrm{VOC}$ chemistry, however, a significant increase in the ozone concentration is projected in both the 21 st and 22nd century (cf. Figure 4 middle and lower panel). 


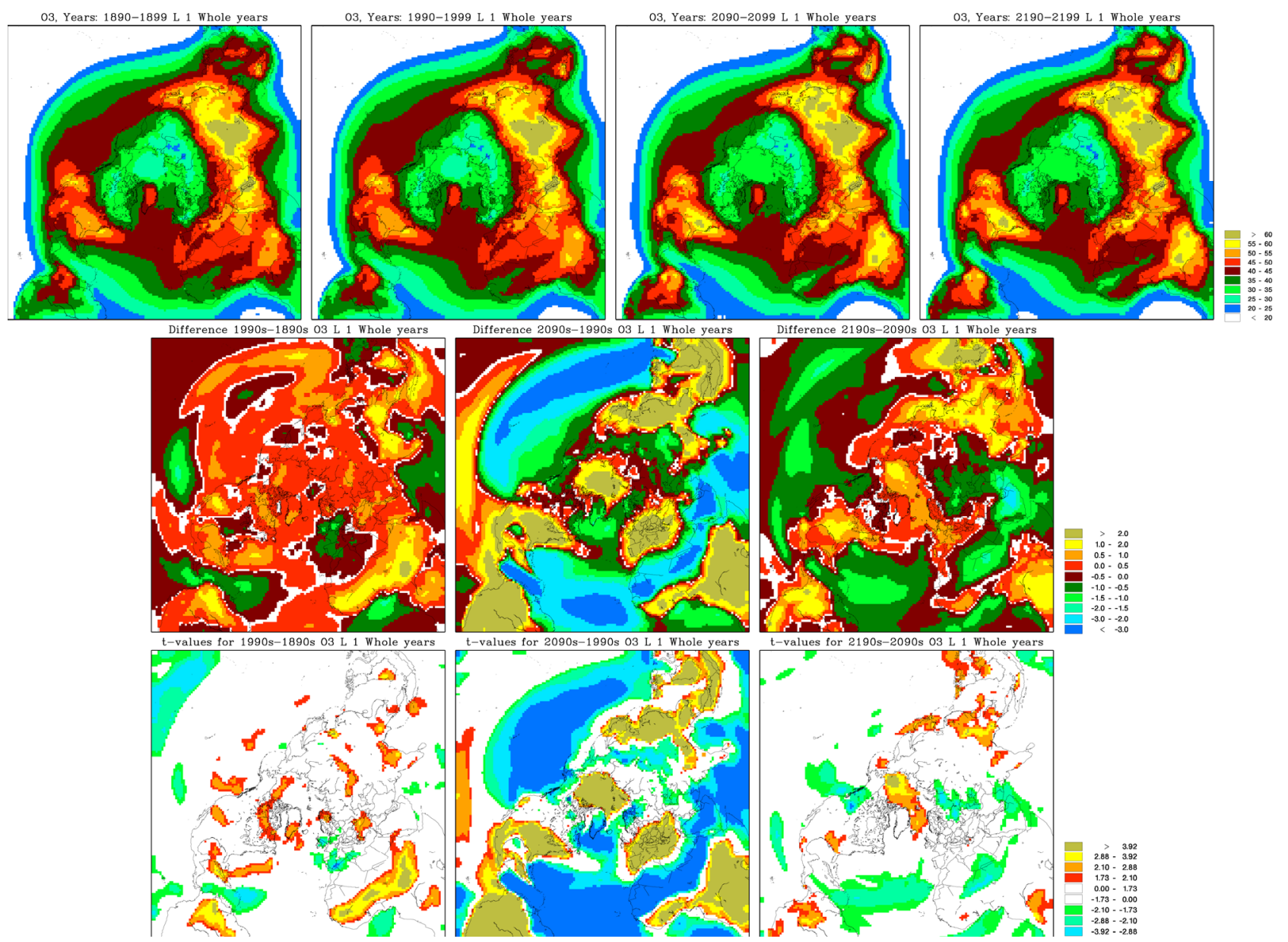

Figure 4. Top panel: Decadal mean surface ozone concentration in ppbV for four decades (1890s, 1990s, 2090s and 2190s). Middle panel: The difference in ppbV. Bottom panel: The significance of the differences according to the students' t-test. The threshold value for significance is $10 \%$ (white areas indicates no significant change).

In Europe the ozone concentration is projected to decrease in the 20st century (1990s-1890s), increase significantly in the current century (2090s-1990s) and continually increase at a lower and insignificant rate in the 22nd century (2290s-1990s) (Figure 4). Since the anthropogenic emissions are kept constant in all three periods the projected change in ozone concentration is solely due to impact of climate change. In order to produce or destroy ozone, sunlight is needed and from Figure 3 it can be seen that the global radiation is projected to increase significantly in most of the domain in the 21st century. Specifically in Europe the ozone concentration projection is very similar to the projected global radiation with a small decrease in the the 20th century, a highly significant increase in the 21 st century and finally a less significant increase in the 22nd century.

The main source of $\mathrm{OH}$ in the atmosphere is photolysis of $\mathrm{O}_{3}$ resulting in exited oxygen $\mathrm{O}\left({ }^{1} \mathrm{D}\right)$ which further reacts with $\mathrm{H}_{2} \mathrm{O}$ to form $\mathrm{OH}$ radicals. In relation to climate change it is important to note that $\mathrm{O}\left({ }^{1} \mathrm{D}\right)$ can either react with $\mathrm{H}_{2} \mathrm{O}$ or collide with $\mathrm{N}_{2}$ or $\mathrm{O}_{2}$ and quenched to ground state oxygen $\mathrm{O}\left({ }^{3} \mathrm{P}\right)$. As the temperature and water vapour increases in the future due to climate change (Figures 1 and 2) reaction with $\mathrm{H}_{2} \mathrm{O}$ is more favourable than the formation of $\mathrm{O}\left({ }^{3} \mathrm{P}\right)$, which in the remote and clean areas leads to a decrease in the ozone concentration. This can be observed in Figure 4, where a decrease of ozone in especially the 21 st century is projected in the remote areas (e.g. over the oceans).

Figure 5 shows the changes of $\mathrm{OH}$ concentrations. Since the hydroxyl radicals determine the oxidation capacity of the atmosphere, they are important when considering pollution levels; e.g. the fate of primary emitted pollutants, formation of ozone and secondary particles. In Figure 5 there is an increasing tendency in the 21 st century over the ocean, in large part of Europe, including Greenland, Arabia, central Asia and to some extend over the ocean in the vicinity of the major international ship routes. The significant increase over the southern the Pacific can be explained by changes projected in the 


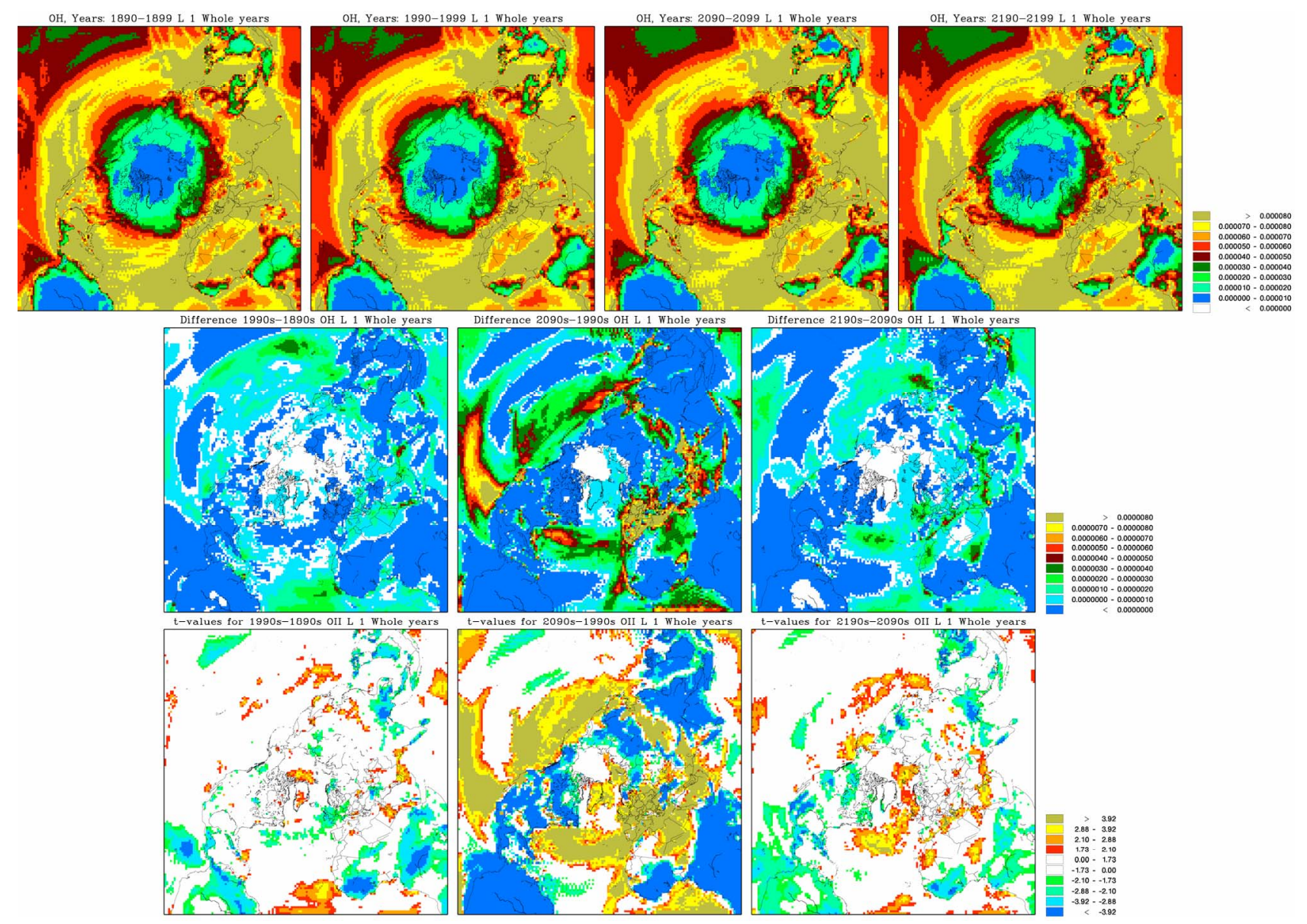

Figure 5. Average decadal concentration of hydroxyl radical $(\mathrm{OH})$ in the lowest model layer in ppbV. Setup the same as in Figure 4.

global radiation and humidity (Figures 2 and 3 ). On the contrary the hydroxyl radical levels are decreasing elsewhere in the domain of interest. In the 20th and 22nd century the picture is more mixed with areas with both significant increasing and decreasing levels, which most likely can be explained by the less significant changes in the solar radiation and specific humidity in these centuries (see Figures $\mathbf{2}$ and $\mathbf{3}$ ).

The oxidation of VOC and CO plays a central role to the overall $\mathrm{O}_{3}$ budget. Non-methane Volatile Organic Compounds (VOCs) can be split into anthropogenic VOCs (AVOCs) ( $10 \%$ of total) and Biogenic VOCs (BVOCs) ( $\sim 90 \%$ of total) (e.g. [35]). In this study the antropogenic emissions have been kept constant in order to separate out the impacts of climate change. In contrast the emissions of BVOCs is free to vary according to the changing climate conditions. Isoprene is the only BVOC included in this model setup. The tropospheric lifetime of isoprene $\mathrm{C}_{5} \mathrm{H}_{8}$ due to its reaction with $\mathrm{OH}$, nitrate $\left(\mathrm{NO}_{3}\right)$ and $\mathrm{O}_{3}$ is $1.4 \mathrm{~h}, 1.6 \mathrm{~h}$ and 1.3 days, respectively (summarized in [36]). Due to this relatively low atmospheric lifetime the highest isoprene concentration (top panel of Figure 6) is found close to the emission sources in especially the tropical areas. Tropical broadleaf trees contributes with almost half of the global isoprene emissions [37], which is in good agreement with the model results shown in the upper panel of Figure 6. In general the isoprene concentration is projected to increase in all three centuries and again with the largest change is found in the 21 st century (see Figure 6). Isoprene is not present in the Arctic region and hence no change is found here (Figure 6).

At daytime (and at all times in the Arctic during the summer) $\mathrm{NO}_{2}$ reacts with ozone to form nitrate radicals, which photolysis fast and hence is of little importance. Contrary, during nighttime substantial concentrations of $\mathrm{NO}_{2}$ can build up affecting the $\mathrm{NO}_{\mathrm{x}}$ chemistry. From field studies it is suggested that $\mathrm{NO}_{3}$ reactions can be a major contributor to isoprene loss at night [38,39]. $\mathrm{NO}_{3}$ react by addition to isoprene at $\mathrm{C}_{1}$ or $\mathrm{C}_{4}$ carbon atom followed by addition of $\mathrm{O}_{2}$ to make a 1.4 addition to form an alkyl nitrate radical. In the model these alkyl nitrates reacts with NO and thus will lead to ozone production at dawn through the photolysis of $\mathrm{NO}_{2}$. This contribution is, however, of minor importance. There is a 


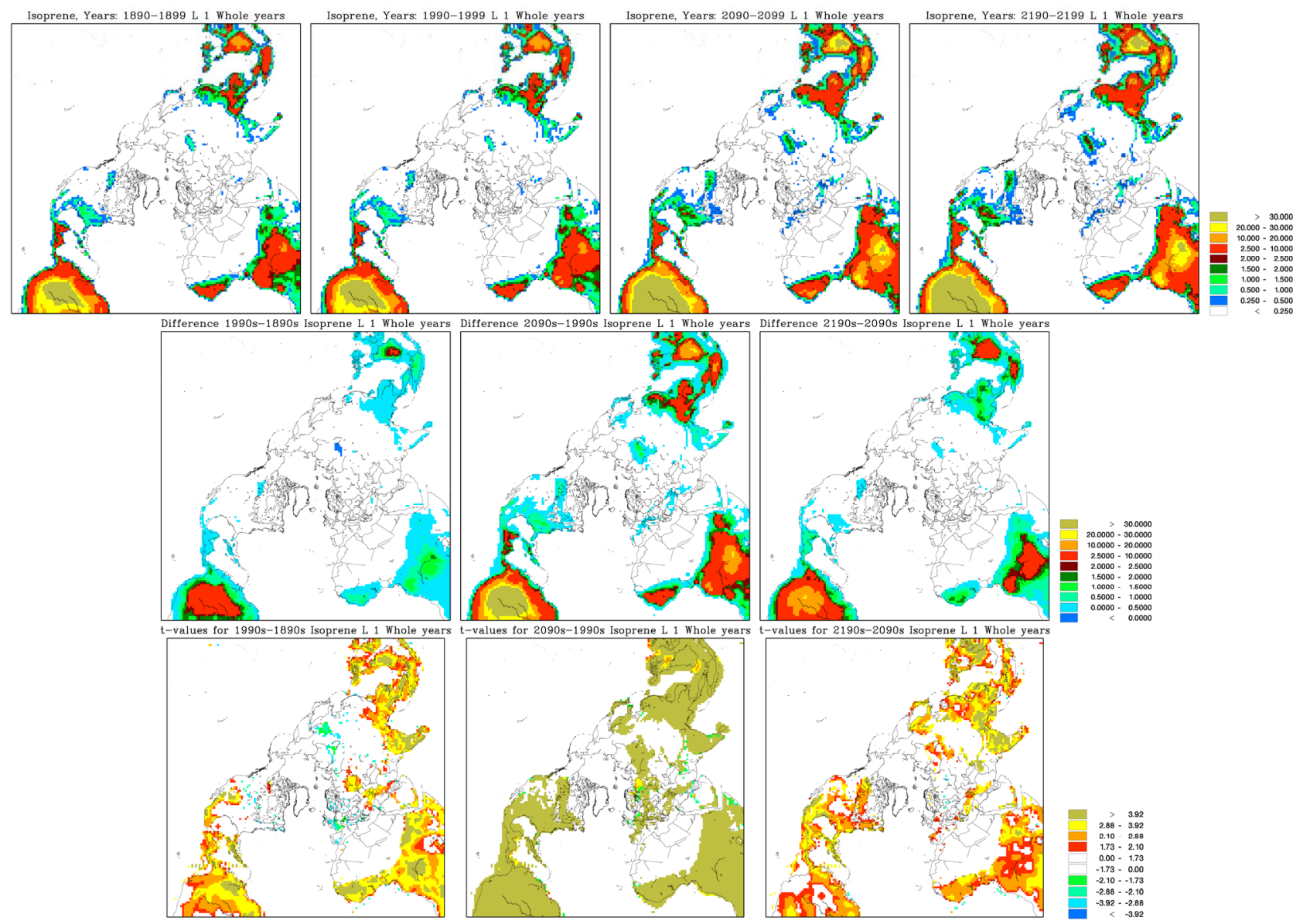

Figure 6. Average decadal concentration of isoprene $\left(\mathrm{C}_{5} \mathrm{H}_{8}\right)$ in the lowest model layer in ppbV. Setup the same as in Figure 4.

discussion in the literature of what will be the fate of these alkyl nitrates. They might self react, react with $\mathrm{NO}_{3}$ radical or with $\mathrm{OH}$ as discussed by [38]. Moreover, $\mathrm{NO}_{3}$ reacts also with $\mathrm{NO}_{2}$ to form $\mathrm{N}_{2} \mathrm{O}_{5}$ which hydrolyses heterogeneously with water to form nitric acid. This last reaction accounts for about the same removal as the reaction between $\mathrm{OH}$ and $\mathrm{NO}_{2}$ at mid latitudes.

In this study it is difficult to isolate the exact impact of $\mathrm{NO}_{3}, \mathrm{O}_{3}$ and $\mathrm{OH}$ on isoprene because many other reactions also occur simultaneously in the simulations and most of the areas with a high emission load of isoprene also to some extent are influenced by anthropogenic sources.

The main source of organic peroxy radicals is from AVOCs and BVOCs. The inorganic peroxy radical can be formed either from the simplest aldehyde ( $\mathrm{HCHO}$ ) or from various reaction of $\mathrm{OH}$ with inorganic oxides $\left(\mathrm{O}_{3}\right.$, $\mathrm{H}_{2} \mathrm{O}_{2}, \mathrm{SO}_{2}$ and $\mathrm{CO}$ ) and the photolysis of carbonyl containing compounds. $\mathrm{HO}_{2}$ is removed either from the reaction with $\mathrm{NO}$ or by its self reaction to form hydrogene peroxide $\left(\mathrm{H}_{2} \mathrm{O}_{2}\right)$ and water. These two processes are competing reactions where reaction with $\mathrm{NO}$ dominates in $\mathrm{NO}_{\mathrm{x}}$ rich areas exposed to high emission from combus- tion processes and the $\mathrm{HO}_{2}$ self reaction is dominating in the free troposphere and in marine environments. The $\mathrm{HO}_{2}$ reaction with $\mathrm{NO}$ results in additional ozone in the atmospheric ozone budget, whereas the self-reaction leads to loss of odd oxygen and by that loss of $\mathrm{O}_{3}$. These features are well represented in the upper panel of Figures 4, 9 and 10, where the highest ozone concentration is coincident with the highest $\mathrm{NO}_{2}$ and $\mathrm{NO}$ concentrations.

Figure 7 shows that the largest increase in hydroperoxy radicals is found in the 21 st century in the "semi-remote" areas, which has a high fraction of vegetation and industry, and in the subtropical and tropical areas. However, a significant increase is also found over most of the domain in the 22nd century. Only in the 20th century the hydroperoxy radical concentration is projected to decrease over the North Atlantic, western Europe and parts of Siberia. The increased concentration of hydroperoxy radicals in the regions with high emissions from vegetation and regions with high emissions from anthropogenic sources, is caused by the increased level of water vapour and isoprene emissions in the future decades. When the water vapour content increases, the $\mathrm{OH}$ concentration increases, due to photolysis of ozone. 


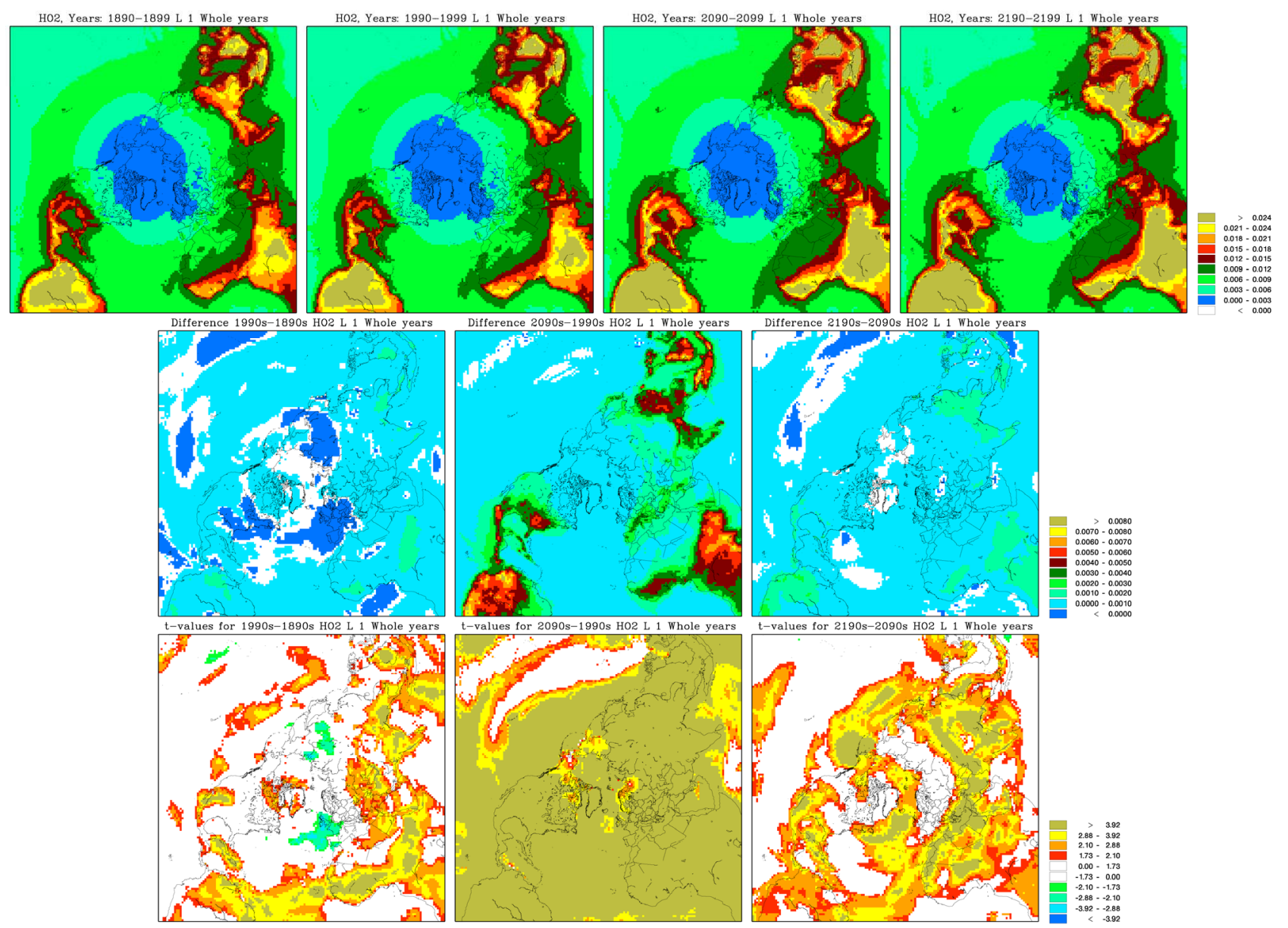

Figure 7. Average decadal concentration of hydroperoxy radical $\left(\mathrm{HO}_{2}\right)$ in the lowest model layer in ppbV. Setup the same as in 4.

The hydroxyl radicals can then be converted to hydroperoxy radicals as described above.

In Figure 8 the changes in organic peroxy radicals over the three centuries are shown. In the 20th century (1990s minus 1890s) the largest increase is found in the Tropics. Organic peroxy radicals are increasing in the 21 st century in most of the domain, whereas the projecttions of the organic peroxy radicals are less significant in the 22nd but still increasing. An increase in organic peroxy radicals can be explained by the same parameters as for hydroperoxy radicals.

In Figure 9 the decadel average concentration in $\mathrm{NO}_{2}$ is shown for the four decades. The picture is mixed with respect to increase and decrease, but the most significant changes are again found in the 21st century (lower panel of Figure 9). Most of the increase is in both the 21st and 22nd century found over the parts of the North Atlantic Ocean, the Arctic Ocean and the northern part of the Pacific Ocean. In contrast $\mathrm{NO}_{2}$ mainly decrease over Europe, South America and Africa in all three centuries.

Figure 10 displays the concentration of NO. Over the
Northwestern part of Europe (Benelux and surroundings) there is an excess of NO. The Benelux area has the worlds largest $\mathrm{NO}_{\mathrm{x}}$ emission density. These high $\mathrm{NO}_{\mathrm{x}}$ emissions imply low $\mathrm{O}_{3}$ concentration in this area, since $\mathrm{O}_{3}$ is used to convert the emitted $\mathrm{NO}$ to $\mathrm{NO}_{2}$.

\section{Discussion}

The changes in the ozone concentration is due to a combined effect of increased temperature, solar radiation, humidity, biogenic isoprene emissions and depends on the chemical regime. In a clean atmosphere, where the $\mathrm{NO}_{\mathrm{x}}$ and AVOC load is low, increased water vapour in the atmosphere acts to reduce the ozone concentration, which is reflected in the projected changes over the oceans in the 21st and 22nd centuries (center panel, Figure 4). However, in regions with moderate to high $\mathrm{NO}_{\mathrm{x}}$ levels, the interaction between the emitted NO and the formed isoprene peroxides from $\mathrm{OH}$, increases the concentration of $\mathrm{HO}_{2}$ (Figure 7) and $\mathrm{NO}_{2}$ (Figure 10), which then enhances the ozone formation. This can explain the higher ozone concentrations in Africa south of Sahara, Southeast 


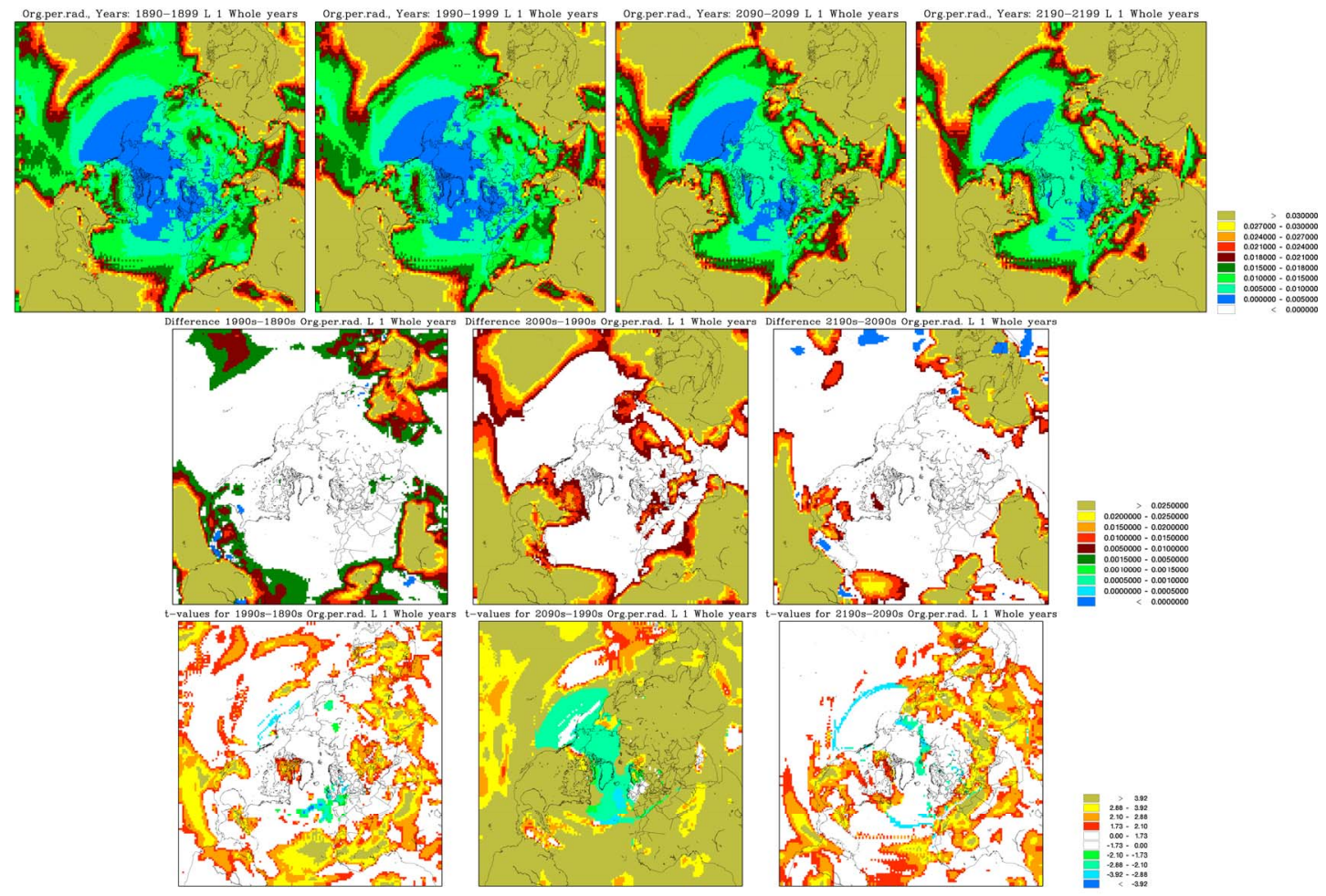

Figure 8. Average decadal concentration of organic peroxy radicals in the lowest model layer in ppbV. Setup the same as in 4.

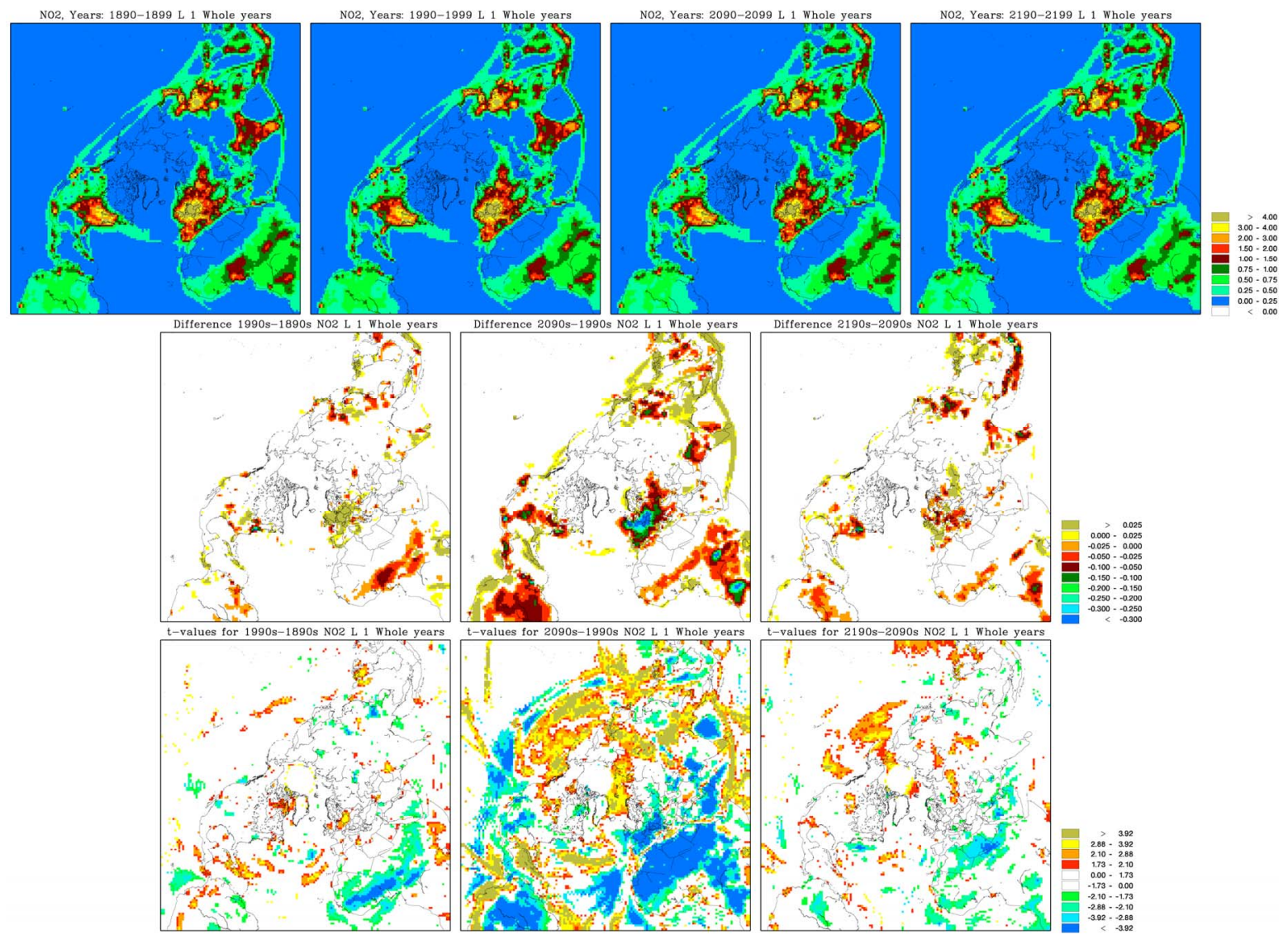

Figure 9. Average decadal concentration of nitrogen dioxide $\left(\mathrm{NO}_{2}\right)$ in the lowest model layer in ppbV. Setup the same as in 4. 


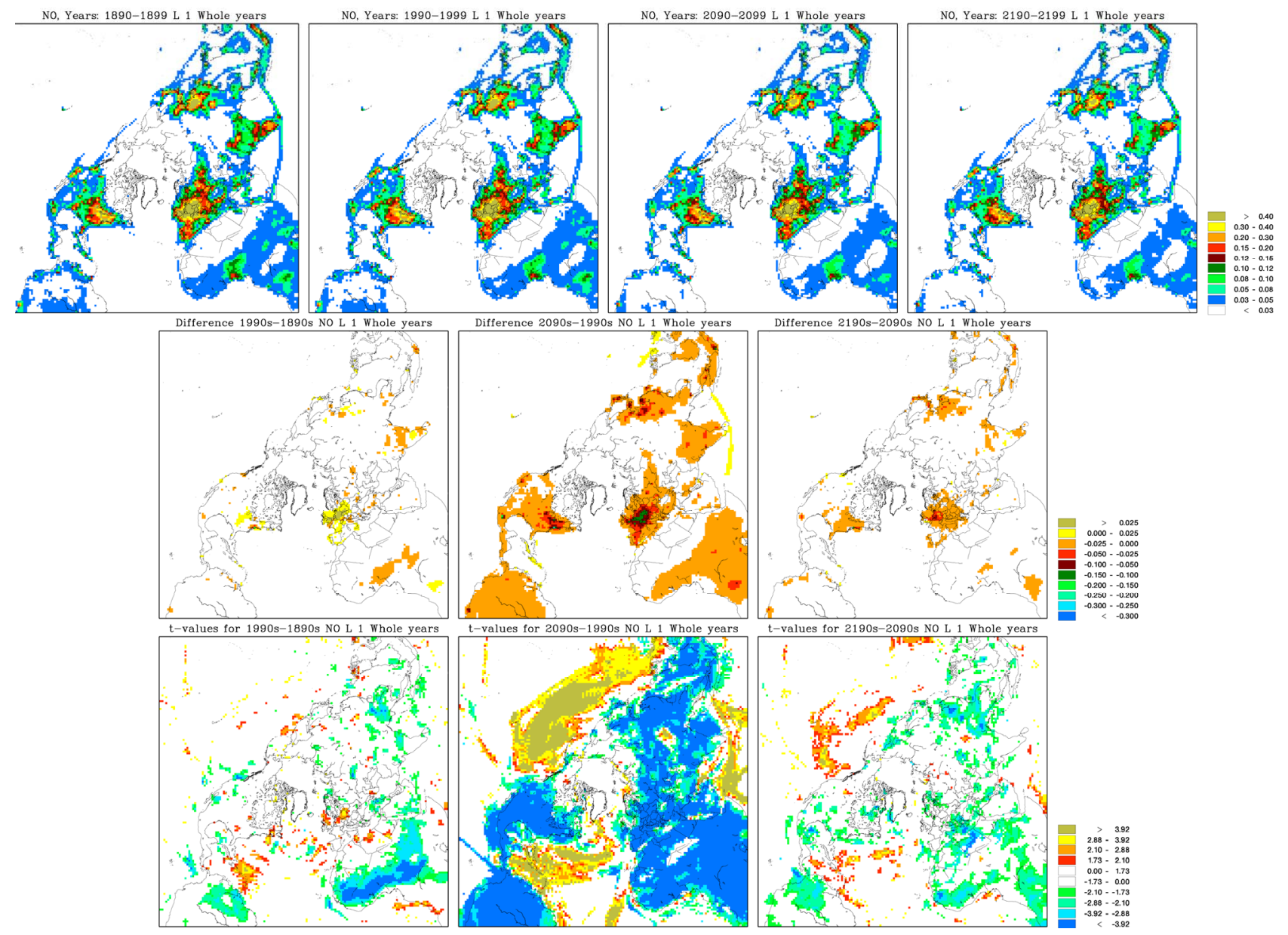

Figure 10. Average decadal concentration of (NO) in the lowest model layer in ppbV. Setup the same as in 4.

Asia and South America (Figure 4). In addition, these areas are covered with a large proportion of tropical plants and tropical rainforest, which emits a large fraction of the ozone precursor, isoprene. Moreover, the isoprene emission itself is increasing in these simula- tions due to changed climate conditions, which can fur- ther amplify the signal in the future ozone concentration.

In the Arctic the ozone concentration is projected to increase throughout all three centuries. However, the change is most significant in the 21 st century. From analysis of each season it is found most significant during the winter season (not shown). In the Arctic region there is no sunlight in the winter months, and hence not any ozone degradation due to photolysis. But since the length of Arctic winter does not change over the centuries with respect to incoming radiation and there is no significant change projected in the global radiation over the Arctic region, further analysis of the ozone related species cannot explain the change over the Arctic region.

Over the Arctic land areas the ozone dry deposition increases (Figure 11), which contributes to the projected decrease in $\mathrm{O}_{3}$ in the air over land (Figure 4). Deposition to vegetative surfaces is much larger than to snow covered surfaces. Hence the projected decrease in snow cover (not shown) can contribute to explain the projected changes in $\mathrm{O}_{3}$ in the 21 st and 22nd century.

Over the Arctic Ocean the temporal and spatial extent of sea ice decreases in the 21 st century (not shown). Ozone does dry deposit to water surfaces in the model $[26,27]$ and the deposition is larger for ice surfaces than for water, which results in a decrease in the dry deposition as the sea ice melts over time. This is in good agreement with the results of the dry deposition (Figure 11), which decreases over the areas of the Arctic ocean, where sea ice extent is decreasing.

Moreover, changes in horizontal transport from the source areas may also contribute to the observed increase in $\mathrm{O}_{3}$ over the Arctic Ocean. If this is the case more ozone is transported into the Arctic from the source areas where increased ozone levels are projected. This additional ozone is compensated by increased deposition over land but amplifies the increase in concentration over the ice free ocean due to a decrease in dry deposition.

Finally vertical downward transport could also in crease 


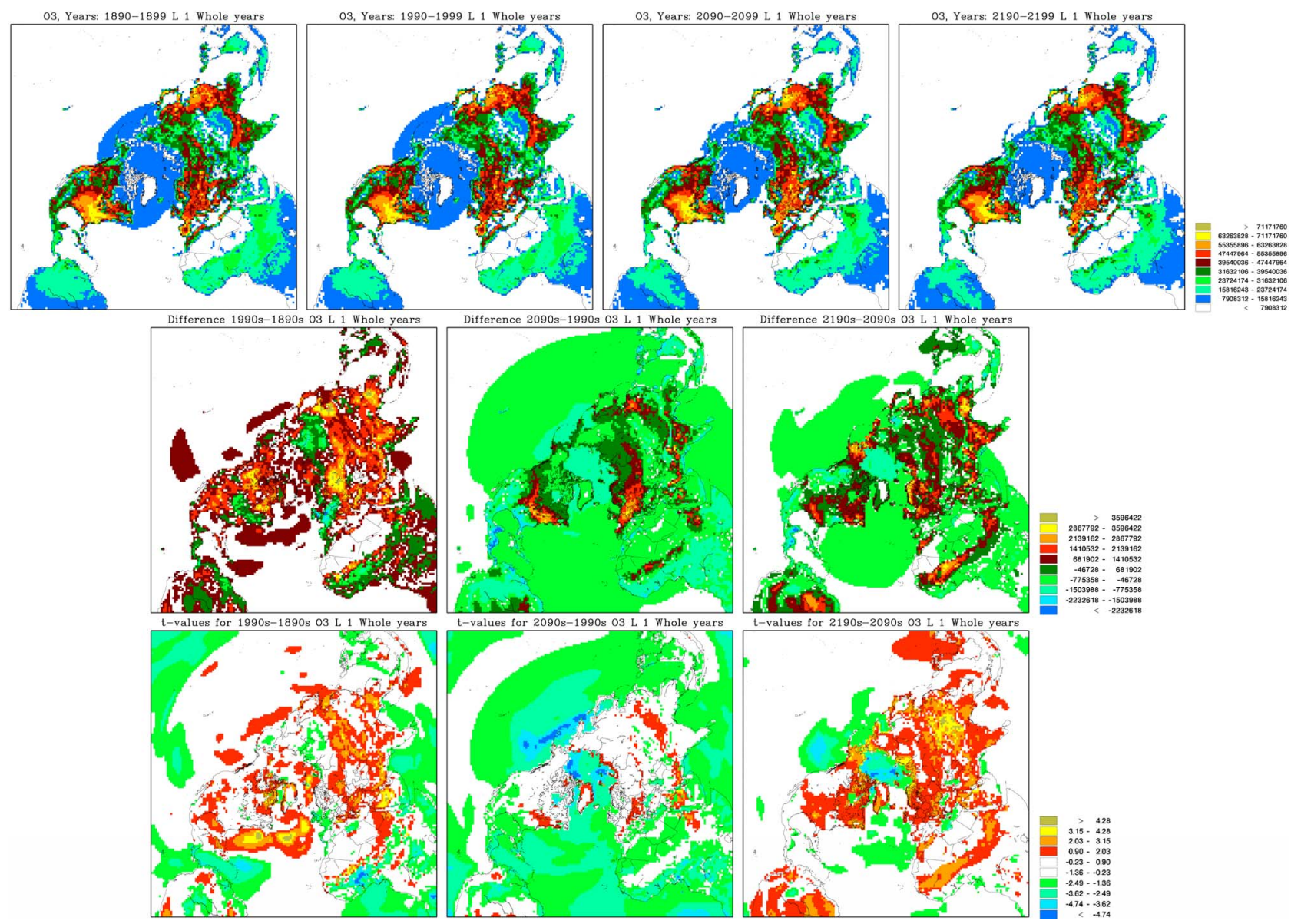

Figure 11. Average decadel ozone dry deposition in $\mathrm{mg} / \mathrm{m}^{-2} / \mathrm{year}$. Setup as in Figure 4.

the concentration of the surface ozone concentration. When entering the free troposphere, the trend in ozone is less confined to the surface and has a more zonal pattern with a highly significant increase within and north of the subtropics and a highly significant decrease in the tropics (Figure 12). In the free troposphere the concentration levels are less influenced by local gradients in emissions and therefore local features are less pronounced. Since the ozone concentrations in general are increasing at higher altitudes, this could contribute with additional ozone at the surface in the future. With the current model setup the stratosphere-troposphere exchange of ozone cannot be expected to be simulated in detail. First of all the model only extents to $100 \mathrm{hPa}$ and secondly the vertical model resolution in the upper atmosphere is relatively poor. Nevertheless, the model includes a rough description of the ozone layer. It is possible that more stratospheric ozone can be produced in the model due to climate change and transported downwards increasing the surface ozone concentrations. Furthermore, the vertical transport patterns can change under changed climate conditions.

Over Europe, East Asia and most of the U.S. (the south-eastern part) the ozone concentrations are estimated to increase due to impacts of climate change. This can be explained by the increased isoprene emission which results from increased temperature. The fact that the future biogenic isoprene emissions are the controlling factor for impacts of climate change on the future ozone concentrations is confirmed in several earlier studies $[3,5,40]$.

In this study the IGAC-GEIA biogenic emission model [34] has been used to calculate the isoprene emission dynamically in the DEHM model. The domain-total annual isoprene emissions is $488 \mathrm{Tg} /$ year for the baseline scenario, which is within the global range $460-770$ $\mathrm{Tg} /$ year found in previous studies $[37,41,42]$.

Since isoprene is the single most important NMVOC for ozone production [43], a correct description of the isoprene emissions is important. Nevertheless to fully describe the emission of isoprene is a complicated task. Since isoprene emissions originate from vegetation it depends on temperature and sunlight. However, investigations have shown that the emission rate of isoprene also depend on the ambient $\mathrm{CO}_{2}$ and $\mathrm{O}_{3}$ concentration, biomass, plant specie, leaf age, soil moisture, wind dam- 
$\mathrm{O}^{3}$ conc. surface
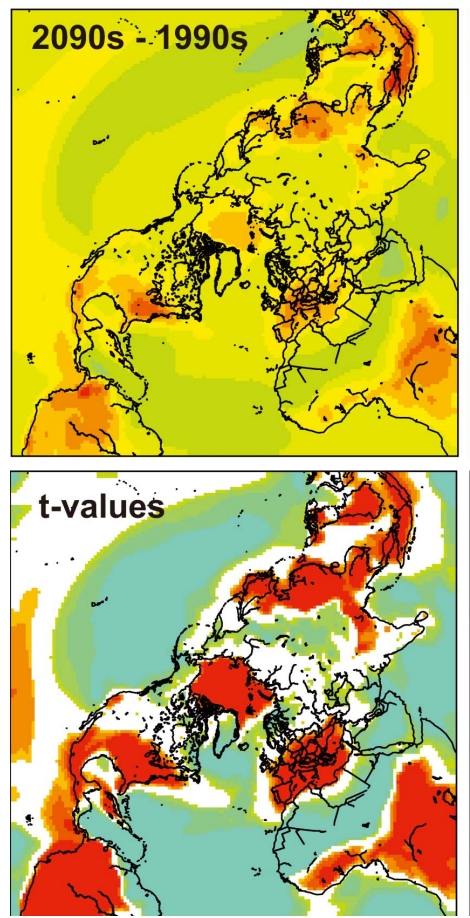

$\mathrm{O}^{3}$ conc. $2 \mathrm{~km}$
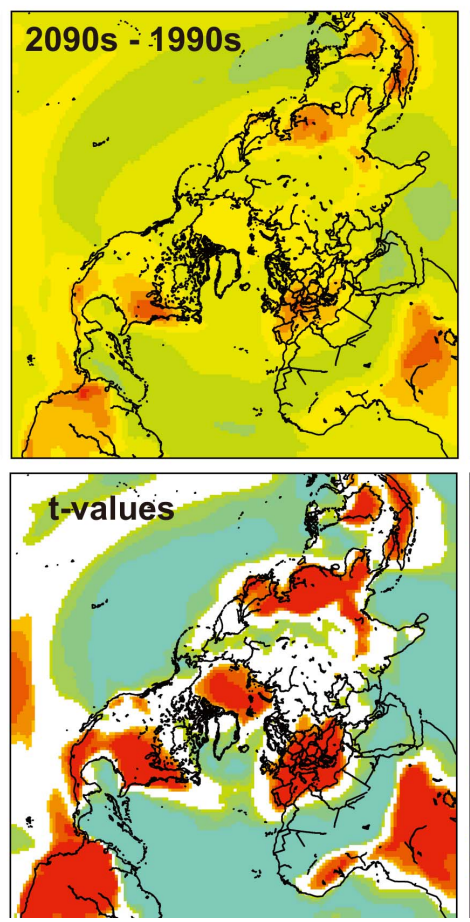

$\mathrm{O}^{3}$ conc. $5 \mathrm{~km}$
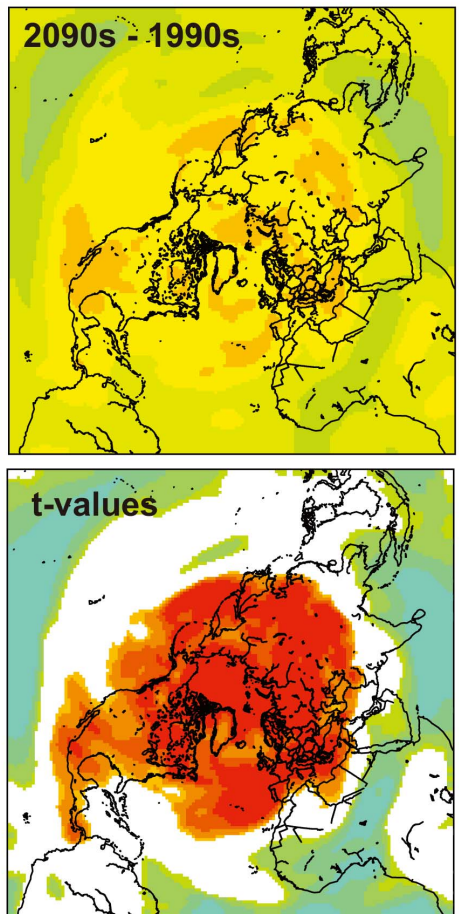

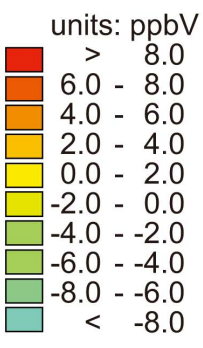

Percentile values

$\longrightarrow \quad 3.92$

$2.88-3.92$

$2.10-2.88$

$1.73-2.10$

$0.00-1.73$

$-1.73-0.00$

$-2.10--1.73$

$-2.88--2.10$

$-3.92--2.88$

$<-3.92$

Figure 12. Changes in ozone concentration in ppbv between the 1990 s to the 2090s and the significance of these changes the surface layer, layer $12(\sim 2100 \mathrm{~m})$ and layer $15(\sim 4750 \mathrm{~m})$.

age etc. [43], but there are large uncertainties connected to each of these variables. For example some studies argues that enhanced ambient $\mathrm{CO} 2$ levels lead to increased isoprene emission due to the resulting increase in biomass and controversially other studies have shown that increased $\mathrm{CO} 2$ levels impact the isoprene synthesis rate for some plant species and hence decrease the isoprene emissions [43].

However, [5] have recently carried out model experiments showing that dry deposition of ozone to vegetation might impact the future ozone concentrations even more. [5] did some sensitivity studies where they changed the description of dry deposition to vegetation to be dependent on several meteorological parameters. When plants are exposed to climate change they change their ozone uptake and here soil moisture is one of the key parameters. When already dry areas, dries out even more, the ozone uptake to vegetation stops and this decreases the dry deposition to vegetation. Particularly [5] found that in Spain this process amounts for $80 \%$ of the total change in ozone.

In the current model setup the EMEP [25] parameterisation has been used and the dry deposition to vegetation depend on changes in meteorology. The dry deposition scheme does, however, not account for the soil moisture effect described by [5].

So far several studies have investigated the impact of climate change over specific regions in the US in the 21st century [2,44-46]. The study by [44] is the only global study and more over the only study including the entire 21 st century. The projection of future ozone is very similar to the projections in this study. The studies by $[2,45]$ only covers projections until year 2050 , hence the results are not comparable.

\section{Conclusions}

In this study a 340 -year long climate simulation from the ECHAM5/MPI-OM model forced with the SRES A1B emission scenario has been used to drive the chemical transport model DEHM. Several DEHM simulations have been carried out with past, present and future meteorology and constant year 2000 anthropogenic emissions in order to isolate the impacts from climate change on the air pollution levels in the Northern Hemisphere. Special emphasis has been put on the analysis of ozone and the related photochemistry in Europe and the Arctic.

The present study illustrates that changes in the ozone concentration due to climate change mainly are driven by two competitive processes; ozone destruction due to increased water vapour in the atmosphere and ozone formation due to increased levels of ozone precursors. Since the anthropogenic emissions have been kept constant in these simulations, biogenic isoprene is the only directly emitted precursor that is free to vary according to the projected climate conditions. Moreover the increase in ozone concentration depends on the $\mathrm{NO}_{\mathrm{x}}$ availability in 
the boundary layer and the future ozone concentration is projected to increase significantly in urban and semiremote areas and to decrease significantly in the remote areas. In the free troposphere the effect from increased water vapour dominates in the tropics while the effect from increased isoprene and changes in transport dominates at high latitudes.

These results show a close relation between the temperature change and the future ozone concentration. The two parameters are not directly connected but are related through a wide range of interacting processes. From the climate simulation it is known that the largest change in temperature is projected to happen in the 21 st century and the same is true for ozone, isoprene, $\mathrm{NO}_{\mathrm{x}}$ and $\mathrm{OH}$. In the 20th century the temperature change is relatively small and in some areas decreasing and other areas increasing. The same patterns are seen in most chemical species e.g. in the $\mathrm{O}_{3}$ concentration. In the 22 nd century the trends are the same as in the 21 st century, but the rate of change decreases for all parameters, which is in good agreement with the constant forcing in the applied climate simulation (constant A1B year-2100 level emission throughout the 22nd century).

Surface ozone is of great importance since high ozone concentrations can have impacts on both humans and nature. This study has shown that at the surface level the background ozone concentration will decrease during the 21 st and the 22nd century. In contrast local ozone in the source areas of precursors (both anthropogenic and biogenic) will increase significantly due to climate change alone. In the free troposphere the ozone concentration will in general increase, except in the tropics where a significant decrease is found. Over the Arctic Ocean a significant increase in surface ozone is found in the future, which can be explained by increased input from the source areas. Moreover, decreased dry deposition of ozone due to increased sea ice and increased import from higher levels can support the projected increase in future surface level ozone in the Arctic region.

Ozone in the atmosphere affects not only the human health and nature. It is also a significant short-lived greenhouse gas in the atmosphere. Today most atmospheric climate models have lower resolution than ACTMs and a more simplified descriptions of the atmospheric physical and chemical processes and therefore account poorly for the feedback from atmospheric chemistry to the climate system. The increase in ozone concentrations in large parts of the upper troposphere could have significant radiative effect, which is not yet accounted for in climate models. To include this and similar chemical feedback effects in the atmosphere, online model or extensive Earth system models are needed. Nevertheless, CTM studies like the present are still necessary in order to study in detail the individual chemical and physical processes in the atmosphere.

\section{Acknowledgements}

This work was partly funded by the Centre for Energy, Environment and Health (CEEH), financed by The Danish Strategic Research Program on Sustainable Energy under contract no 2104-06-0027 (www.ceeh.dk).

\section{REFERENCES}

[1] S. L. Wu, L. J. Mickley, D. J. Jacob, D. Rind and D. G. Streets, "Effects of 2000-2050 Changes in Climate and Emissions on Global Tropospheric Ozone and the Policy-Relevant Background Ozone in the United States," Journal of Geophysical Research, Vol. 113, 2008, Article ID: D18312.

[2] P. N. Racherla and P. J. Adams, "The Response of Surface Ozone to Climate Change over Eastern United States," Atmospheric Chemistry and Physics, Vol. 8, No. 4, 2008, pp. 871-885. doi:10.5194/acp-8-871-2008

[3] G. B. Hedegaard, J. Brandt, J. H. Christensen, L. M. Frohn, C. Geels, K. M. Hansen and M. Stendel, "Impacts of Climate Change on Air Pollution Levels in the Northern Hemisphere with Special Focus on Europe and the Arctic," Atmospheric Chemistry and Physics, Vol. 8, No. 12, 2008, pp. 3337-3367. doi:10.5194/acp-8-3337-2008

[4] E. Katragkou, P. Zanis, I. Tegoulias, D. Melas, I. Kioutsioukis, B. C. Krger, P. Huszar, T. Halenka and S. Rauscher, "Decadal Regional Air Quality Simulations over Europe in Present Climate: Near Surface Ozone Sensitivity to External Meteorological Forcing," Atmospheric Chemistry and Physics, Vol. 10, 2010, pp. 11805-11821.

[5] C. Andersson and M. Engardt, "European Ozone in a Future Climate: Importance of Changes in Dry Deposition and Isoprene Emissions," Journal of Geophysical Research, Vol. 115, No. D2, 2010, Article ID: D02303. doi:10.1029/2008JD011690

[6] J. Langner, M. Engardt, A. Baklanov, J. Christensen, M. Gauss, C. Geels, G. B. Hedegaard, R. Nuterman, D. Simpson, J. Soares, M. Sofiev, P. Wind and A. Zakey, "A Multi-Model Study of Impacts of Climate Change on Surface Ozone in Europe," Atmospheric Chemistry and Physics, Vol. 12, No. 2, 2012, pp. 4901-4939. doi:10.5194/acpd-12-4901-2012

[7] E. Roeckner, G. Bauml, L. Bonaventura, R. Brokopf, M. Esch, M. Giorgetta, S. Hagemann, I. Kirchner, L. Kornblueh, E. Manzini, A. Rhodin, U. Schlese, U. Schulzweida and A. Tompkins, "The Atmospheric General Circulation Model ECHAM5, Part I,” Max-Planck-Institute für Meteorologie, Hamburg, 2003.

[8] E. Roeckner, R. Brokopf, M. Esch, M. Giorgetta, S. Hagemann, E. Kornblueh, L. Manzini, U. Schlese and U. Schulzweida, "Sensitivity of Simulated Climate to Horizontal and Vertical Resolution in the ECHAM5 Atmosphere Model," Journal of Climate, Vol. 19, No. 16, 2006, pp. 3771-3791. doi:10.1175/JCLI3824.1

[9] S. J. Marsland, H. Haak, J. H. Jungclaus, M. Latif and F. Roske, "The Max-Planck-Institute Global Ocean/Sea Ice 
Model with Orthogonal Curvilinear Coordinates," Ocean Modelling, Vol. 5, No. 2, 2003, pp. 91-127. doi:10.1016/S1463-5003(02)00015-X

[10] W. May, "Climatic Changes Associated with a Global 2 Degrees C-Stabilization Scenario Simulated by the EC HAM5/MPI-OM Coupled Climate Model," Climate Dynamics, Vol. 31, No. 2-3, 2008, pp. 283-313. doi: $10.1007 / \mathrm{s} 00382-007-0352-8$

[11] J. H. Jungclaus, N. Keenlyside, M. Botzet, H. Haak, J. J. Luo, M. Latif, J. Marotzke, U. Mikolajewicz and E. Roeckner, "Ocean Circulation and Tropical Variability in the Coupled Model ECHAM5/MPI-OM," Journal of Climate, Vol. 19, No. 16, 2006, pp. 3952-3972. doi:10.1175/JCLI3827.1

[12] N. Nakicenovic, J. Alcamo, G. Davis, B. de Vries, J. Fenhann, S. Gaffin, K. Gregory, A. Grbler, T. Jung, T. Kram, E. L. Rovere, L. Michaelis, S. Mori, T. Morita, W. Pepper, H. Pitcher, L. Price, K. Riahi, A. Roehrl, H.-H. Rogner, A. Sankovski, M. Schlesinger, P. Shukla, S. Smith, R. Swart, S. van Rooijen, N. Victor and Z. Dadi, "Special Report on Emission Scenarios: A Special Report of Working Group III of the Intergovernmental Panel on Climate Change," Cambridge University Press, New York, 2000.

[13] G. A. Meehl, T. F. Stocker, W. D. Collins, P. Friedlingstein, A. T. Gaye, J. M. Gregory, A. Kitoh, R. Knutti, J. M. Murphy, A. Noda, S. C. B. Raper, I. G. Watterson, A. J. Weaver and Z.-C. Zhao, "Climate Change 2007: The Physical Science Basis," In: Contribution of Working Group I to the Fourth Assessment Report of the Intergovernmental Panel on Climate Change Global Climate Projections, Cambridge University Press, Cambridge and New York, 2007, pp. 747-846.

[14] M. R. Spiegel, "Schaum's Outline of Theory and Problems of Statistics," 2nd Edition, McGraw-Hill, New York, 1992.

[15] H. Goosse, P. Y. Barriat, W. Lefebvre, M. F. Loutre and V. Zunz, "Introduction to Climate Dynamics and Climate Modelling," 2009. http://stratus.astr.ucl.ac.be/textbook/

[16] G. B. Hedegaard, "Impacts of Climate Change on Air Pollution Levels in the Northern Hemisphere," Technical Report 240, National Environmental Research Institute, Roskilde, 2007. www.dmu.dk

[17] J. H. Christensen, C. Hewitt, A. Busuioc, A. Chen, X. Gao, I. Held, R. Jones, R. K. Kolli, W.-T. Kwon, R. Laprise, V. Magaa Rueda, L. Mearns, C. G. Menendez, J. Risnen, A. Rinke, A. Sarr and P. Whetton, "Climate Change 2007: The Physical Science Basis," In: Contribution of Working Group I to the Fourth Assessment Report of the Intergovernmental Panel on Climate Change Regional Climate Projections, Cambridge University Press, Cambridge, 2007, pp. 847-940.

[18] R. Vautard and D. Hauglustaine, "Impact of Global Climate Change on Regional Air Quality: Introduction to the Thematic Issue," Comptes Rendus Geoscience, Vol. 339, No. 11-12, 2007, pp. 703-708. doi:10.1016/j.crte.2007.08.012

[19] P. A. Stott, D. A. Stone and M. R. Allen, "Human Contribution to the European Heatwave of 2003," Nature, Vol.
432, 2004, pp. 610-614. doi:10.1038/nature03089

[20] J. H. Christensen, "The Danish Eulerian Hemispheric Model-A Three-Dimensional Air Pollution Model Used for the Arctic," Atmospheric Environment, Vol. 31, No. 24, 1997, pp. 4169-4191. doi:10.1016/S1352-2310(97)00264-1

[21] L. M. Frohn, "A Study of Long-Term Highresolution Air Pollution Modelling," Ph.D. Dissertation, University of Copenhagen and National Environmental Research Institute, Copenhagen, 2004.

[22] J. Brandt, J. D. Silver, L. M. Frohn, C. Geels, A. Gross, A. B. Hansen, K. M. Hansen, G. B. Hedegaard, C. A. Skjøth, H. Villadsen, A. Zare and J. H. Christensen, "An Integrated Model Study for Europe and North America Using the Danish Eulerian Hemispheric Model with Focus on Intercontinental Transport of Air Pollution," Atmospheric Environment, Vol. 53, 2012, pp. 156-176.

doi:10.1016/j.atmosenv.2012.01.011

[23] G. B. Hedegaard, "Future Air Pollution Levels in the Northern Hemisphere-Sensitivity to Climate Change and Projected Emissions," Ph.D. Thesis, Aarhus University, Aarhus, 2011.

[24] J. A. Logan, “An Analysis of Ozonesonde Data for the Troposphere: Recommendations for Testing 3-D Models and Development of a Gridded Climatology for Tropospheric Ozone," Journal of Geophysical Research, Vol. 104, No. D13, 1999, pp. 115-116. doi:10.1029/1998JD100096

[25] D. Simpson, H. Fagerli, J. Jonson, S. Tsyro, P. Wind and J.-P. Touvinen, "Transboundary Acidification, Eutrophication and Ground Level Ozone in Europe, Part I," Norwegian Meteorological Institute, Unified EMEP Model description EMEP MSC-W, Oslo, 2003.

[26] W. A. H. Asman, L. L. Sensen, R. Berkowicz, K. Granby, H. Nielsen, B. Jensen, E. Runge, C. Lykkelund, S. E. Gryning and A. M. Sempreviva, "Dry Deposition Processes," Marine Research 35, Danish Environmental Protection Agency, Copenhagen, 1994.

[27] O. Hertel, J. Christensen, E. H. Runge, W. A. H. Asman, R. Berkowicz and M. F. Hovmand, "Development and Testing of a New Variable Scale Pollution ModelACDEP," Atmospheric Environment, Vol. 29, No. 11, 1995, pp. 1267-1290. doi:10.1016/1352-2310(95)00067-9

[28] L. M. Frohn, J. H. Christensen, J. Brandt and O. Hertel, "Development of a High Resolution Integrated Nested Model for Studying Air Pollution in Denmark," Physics and Chemistry of the Earth, Vol. 26, Part B, 2001, pp. 769-774.

[29] L. M. Frohn, J. H. Christensen and J. Brandt, "Development and Testing of Numerical Methods for Two-Way Nested Air Pollution Modelling," Physics and Chemistry of the Earth, Vol. 27, No. 35, 2002, pp. 1487-1494. doi:10.1016/S1474-7065(02)00151-1

[30] L. M. Frohn, J. H. Christensen and J. Brandt, "Development of a High-Resolution Nested Air Pollution Model: The Numerical Approach," Journal of Computational Physics, Vol. 179, No. 1, 2002, pp. 68-94. doi: $10.1006 /$ jcph.2002.7036

[31] T. Graedel, T. Bates, A. Bouwman, D. Cunnold, J. Dignon, 
I. Fung, D. Jacob, B. Lamb, J. Logan, G. Marland, P. Middleton, J. Pacyna, M. Placet and C. Veldt, "A Compilation of Inventories of Emissions to the Atmosphere," Global Biogeochemical Cycles, Vol. 7, No. 1, 1993, pp. 1-26. doi:10.1029/92GB02793

[32] J. Olivier, A. Bouwman, C. van der Maas, J. Berdowski, C. Veldt, J. Bloos, A. Visschedijk, P. Zandveld and J. Haverlag, "Description of EDGAR Version 2.0: A Set of Global Emission Inventories of Greenhouse Gases and Ozone-Depleting Substances for All Anthropogenic and Most Natural Sources on a Per Country Basis and on 1 Degree $\times 1$ Degree Grid," National Institute for Public Health and the Environment (RIVM), Bilthoven, 1996.

[33] V. Vestreng, "Emission Data Reported to UNECE/ EMEP: Evaluation of the Spatial Distribution of Emission," MSC-W Status Report, Meteorological Synthesizing Centre-West, Oslo, 2001.

[34] A. Guenther, C. Hewitt, D. Erickson, R. Fall, C. Geron, T. Graedel, P. Harley, L. Klinger, M. Lerdau, W. McKay, T. Pierce, B. Scholes, R. Steinbrecher, R. Tallamraju, J. Taylor and P. Zimmerman, "A Global-Model of Natural Volatile Organic-Compound Emissions," Journal of Geophysical Research, Vol. 100, No. D5, 1995, pp. 88738892. doi:10.1029/94JD02950

[35] A. H. Goldstein and I. E. Galbally, "Known and Unexplored Organic Constituents in the Earths Atmosphere," Environmental Science \& Technology, Vol. 41, No. 5, 2007, pp. 1514-1521. doi:10.1021/es072476p

[36] G. B. Hedegaard, "Air Pollution-From a Local to a Global Perspective,” Polyteknisk Forlag, Lyngby, 2009, pp. 163-174.

[37] A. Guenther, T. Karl, P. Harley, C. Wiedinmyer, P. I. Palmer and C. Geron, "Estimates of Global Terrestrial Isoprene Emissions Using MEGAN (Model of Emissions of Gases and Aerosols from Nature)," Atmospheric Chemistry and Physics, Vol. 6, No. 11, 2006, pp. 31813210. doi:10.5194/acp-6-3181-2006

[38] A. W. Rollins, A. Kiendler-Scharr, J. L. Fry, T. Brauers, S. S. Brown, H.-P. Dorn, W. P. Dube, H. Fuchs, A. Mensah, T. F. Mentel, F. Rohrer, R. Tillmann, R. Wegener, P. J. Wooldridge and R. C. Cohen, "Isoprene Oxidation by Nitrate Radical: Alkyl Nitrate and Secondary Organic Aerosol Yields," Atmospheric Chemistry and Physics, Vol. 9, No. 18, 2009, pp. 6685-6703. doi:10.5194/acp-9-6685-2009

[39] H. Skov, J. Hjorth, C. Lohse, N. R. Jensen and G. Restelli, "Products and Mechanisms of the Reactions of the Nitrate Radical $\left(\mathrm{NO}_{3}\right)$ with Isoprene, 1,3-Butadiene and 2,3-Dimethyl-1,3-Butadiene in Air," Atmospheric Environment: Part A. General Topics, Vol. 26, No. 15, 1992, pp. 27712783. doi:10.1016/0960-1686(92)90015-D

[40] Y. F. Lam, J. S. Fu and L. J. Mickley, "Impacts of Future Climate Change and Effects of Biogenic Emissions on Surface Ozone and Particulate Matter Concentrations in the United States," Atmospheric Chemistry and Physics, Vol. 11, No. 10, 2011, pp. 4789-4806. doi:10.5194/acp-11-4789-2011

[41] A. Arneth, R. K. Monson, G. Schurgers, U. Niinemets and P. I. Palmer, "Why Are Estimates of Global Terrestrial Isoprene Emissions So Similar (and Why Is This Not so for Monoterpenes)?" Atmospheric Chemistry and Physics, Vol. 8, No. 16, 2008, pp. 4605-4620.

[42] K. Ashworth, O. Wild and C. N. Hewitt, "Sensitivity of Isoprene Emissions Estimated Using Megan to the Time Resolution of Input Climate Data," Atmospheric Chemistry and Physics, Vol. 10, No. 3, 2010, pp. 1193-1201. doi:10.5194/acp-10-1193-2010

[43] D. Fowler, M. Amann, R. Anderson, M. Ashmore, P. Cox, M. D. M, D. Derwent, P. Grennfelt, N. Hewitt, O. Hov, M. Jenkin, F. Kelly, P. Liss, M. Pilling, J. Pyle, J. Slingo and D. Stefenson, "Ground-Level Ozone in the 21st Century: Future Trends, Impacts and Policy Implications," Science Policy Report 15/08, The Royal Society, London, 2008.

[44] K. Murazaki and P. Hess, "How Does Climate Change Contribute to Surface Ozone Change over the United States," Journal of Geophysical Research, Vol. 111, No. D05301, 2006, 16 pp. doi:10.1029/2005JD005873

[45] S. Wu, L. J. Mickley, E. M. Leibensperger, D. J. Jacob, D. Rind and D. G. Streets, "Effects of 2000-2050 Global Change on Ozone Air Quality in the United States," Journal of Geophysical Research, Vol. 113, 2008, Article ID: D06302.

[46] H. Liao, Y. Zhang, W.-T. Chen, F. Raes and J. H. Seinfeld, "Effect of Chemistry-Aerosol-Climate Coupling on Predictions of Future Climate and Future Levels of Tropospheric Ozone and Aerosols," Journal of Geophysical Research, Vol. 114, 2009, Article ID: D10306. 